\title{
Effect of Afghan Ferula assa-foetida L. and Crocus Sativus L. Aqueous Extracts Combination on Withdrawal Signs in Morphine-Dependent Rats
}

\author{
Ali Yousofi ${ }^{1}$, Kawsar Alami ${ }^{1}$, Sayed Yousof Mousavi ${ }^{2, *}$ \\ ${ }^{1}$ Research and Technology Center, Khatam Al-Nabieen University, Kabul, Afghanistan \\ ${ }^{2}$ Department of Physiology, Khatam Al-Nabieen University, 1st Street of Karte 4, Kabul, Afghanistan
}

Received April 20, 2021; Revised June 4, 2021; Accepted June 28, 2021

\section{Cite This Paper in the following Citation Styles}

(a): [1] Ali Yousofi, Kawsar Alami, Sayed Yousof Mousavi, "Effect of Afghan Ferula assa-foetida L. and Crocus Sativus L. Aqueous Extracts Combination on Withdrawal Signs in Morphine-Dependent Rats," Advances in Pharmacology and Pharmacy, Vol. 9, No. 3, pp. 56 - 64, 2021. DOI: 10.13189/app.2021.090303.

(b): Ali Yousofi, Kawsar Alami, Sayed Yousof Mousavi (2021). Effect of Afghan Ferula assa-foetida L. and Crocus Sativus L. Aqueous Extracts Combination on Withdrawal Signs in Morphine-Dependent Rats. Advances in Pharmacology and Pharmacy, 9(3), 56 - 64. DOI: 10.13189/app.2021.090303.

Copyright $\bigcirc 2021$ by authors, all rights reserved. Authors agree that this article remains permanently open access under the terms of the Creative Commons Attribution License 4.0 International License

\begin{abstract}
The purpose of this study is to evaluate the effect of Afghan Ferula assa-foetida L. and Crocus Sativus $L$. aqueous extracts either alone or in combination on morphine withdrawal signs. For this purpose, rats were randomly divided into 13 groups (1 Normal, 1 Morphine, 4 Ferula assa-foetida-treated groups, 4 Crocus sativus-treated groups, and 3 combination groups). Morphine dependency was rendered by subcutaneous injection of morphine hydrochloride for 4 days $(10,20$ and $40 \mathrm{mg} / \mathrm{kg}$ doses twice daily for 3 days and a single dose of $60 \mathrm{mg} / \mathrm{kg}$ on 4th day). Various doses of extracts were injected into extract groups simultaneously with morphine. After two hours of last morphine administration, withdrawal signs were induced by naloxone $(3 \mathrm{mg} / \mathrm{kg})$ and noted for 30 minutes. According to the results, different doses of Ferula assa-foetida and Crocus sativus extracts and their combination (in low dose) could significantly decrease the number of morphine withdrawal signs $(\mathrm{P}<0.05)$. However, the combination of Ferula assa-foetida and Crocus sativus extracts in high doses showed toxic effects. In conclusion, Ferula assa-foetida and Crocus sativus extract combination in low dose can decrease the morphine withdrawal signs, but without any synergic effects.
\end{abstract}

Keywords Afghanistan, Ferula assa-foetida, Crocus sativus, Combination, Morphine Withdrawal Signs, Rats

\section{Introduction}

Morphine and other opioids are known as the most potent analgesic drugs. These drugs are widely used for alleviation of acute and chronic pain [1-3]. However, use of morphine for a long-term period can induce adaptive changes in the brain that are responsible for morphine tolerance and dependency development [4,5]. Morphine dependency is a recurrent, chronic disorder, associated with intensive desire and unlimited use of morphine with inappropriate social and occupational behavior [6,7]. Lack of morphine leads to the development of many withdrawal signs including pain, sweating, tachycardia, insomnia, depression and anxiety [8].

Multiple neurotransmitter systems are involved in opioid dependency and withdrawal signs, including GABAergic, dopaminergic, orexinergic and noradrenergic [9-15].

Because of the increase in world prevalence of morphine dependency, many attempts have made to treat the morphine dependency and especially decrease the withdrawal signs [8]. Studies showed that natural products including nuts and plants are the best choices for the treatment of multiple disorders such as morphine dependency. Natural products are known for their fewer side effects and potent biological activities than synthetic drugs [8,16-19]. There are pieces of evidence that the use of herbal combinations in the treatment of diseases has a 
better effect than that of individual herbs. Thus, many researchers have encouraged using polyherbal formulations [20,21]. However, there are reports that herbal combinations interaction may be as synergy, antagonist and additive/indifferent [22].

Ferula assa-foetida is a herb from Apiaceae family [23]. Its oleo gum resin found in two, mass and tear forms and has many beneficial constituents [24]. Ferula assa-foetida oleo gum resin is mainly constituted by resin, gum and essential volatile oils. The resin fractions include many terpenoids, coumarins and especially ferulic acid and its ester $[25,26]$. Studies showed that Ferula assa-foetida oleo gum resin possessed biological activities such as anti-hyperglycemic [26], anti-oxidant [27], anti-nociceptive and anti-inflammatory [28]. In addition, administration of different parts of Ferula assa-foetida including areal parts, flower and root could decrease the withdrawal signs in morphine-dependent rats [29]. There are many reports that indicate the beneficial effects of this plant are greatly depending to its constituents, such as ferulic acid and caffeic acid [29,30]. Ferulic acid can inhibit nitric oxide isoforms [31], and the production of LPS-induced nitric oxide also can be inhibited by isolated caffeic acid from Ferula assa-foetida [32]. As the locus coeruleus's activity can be modulated by nitric oxide pathway, inhibition of nitric oxide can decrease the morphine withdrawal signs [33,34]. Thus, Ferula assa-foetida may decrease morphine withdrawal signs through inhibition of nitric oxide pathway $[29,30]$.

Crocus sativus or saffron is another medicinal plant from Iridaceae family [35]. This plant is also known as kings of the world's medicines. Crocus sativus mainly contains crocin, picrocrocin and safranal [36,37]. It has many pharmacological effects such as anti-oxidant [35], memory-enhancing [38], anti-inflammatory and anti-nociceptive [39]. In addition, this plant has beneficial effects on morphine dependency treatment and reduction of morphine withdrawal signs $[37,40]$. Previous studies have related the effects of this plant on morphine withdrawal to its main constituent, crocin, which can decrease the morphine withdrawal signs [40]. It is also suggested that Crocus sativus effects on GABA-A benzodiazepine receptors can facilitate GABA actions, which lead to sedative and anti-anxiety effects and thus reduce the morphine withdrawal signs. Also, the effectiveness of Crocus sativus on morphine withdrawal may be related with its effect on release of dopamine in brain, which can alleviate morphine withdrawal signs through interaction with D2 receptors in nucleus accumbence [37].

Because of the beneficial properties of Ferula assa-foetida and Crocus sativus in the treatment of morphine dependency [29,37] and better outcomes of herbs combinations in the treatment of disease [21], the present study investigates the effect of Ferula assa-foetida and Crocus sativus extracts either alone or in combination on morphine withdrawal signs, using behavioral method.

\section{Materials and Methods}

\subsection{Materials}

The important instruments and materials of this study include Ferula assa-foetida oleo gum resin, Crocus sativus stigma (Afghanistan), naloxone hydrochloride (Toliddaru Pharma. Co. Tehran-Iran), morphine hydrochloride (idol ilaç Dolum San. and Tic. A.Ș. Topkap1-Istanbul), and glass cylinders.

\subsection{Animals}

Seventy-eight adult Sprague-Dawley male rats (150 to $200 \mathrm{~g}$ ), were selected from Research and Technology Center of Khatam Al-Nabieen University (KNURTC) randomly. Rats were housed under stable room temperature $\left(23 \pm 2^{\circ} \mathrm{C}\right)$ and a 12 hours light/dark cycle (the light period started at 7 a.m.), in Plexy-glass cages with free access to food and water. The experimental protocol related to animal's use was based on ethical guidelines set by the $8^{\text {th }}$ edition of the National Institute of Health (NIH) guide for the care and use of laboratory animals, so approved by the Khatam Al-Nabieen University ethic research board. For minimizing unwanted stress during experiments and housing, rats were handled carefully.

\subsection{Plant Collection and Extraction}

Ferula assa-foetida: Fresh oleo gum resin of Ferula assa-foetida in mass form was gathered from Temran, Daikundi province of Afghanistan, dried in the shade and powdered. $10 \mathrm{mg}$ of its powder was macerated in $100-\mathrm{ml}$ distilled water overnight, and filtered. As a result, Ferula assa-foetida aqueous extract (FAAE) was obtained [25].

Crocus sativus: Fresh stigmas of Crocus sativus were collected from Khaja sarbar, Herat province of Afghanistan. Stigmas were dried and then grinded. The extraction was done by maceration of $4 \mathrm{~g}$ of stigma's powder in $500 \mathrm{ml}$ distilled water and keeping it for 3 days at room temperature. Then, the supernatant was collected by centrifuging, filtered and evaporated at $50^{\circ} \mathrm{C}$. As a result, Crocus sativus aqueous extract (CSAE) was obtained [37].

Both plants were identified by Prof. Nasim Sediqi, Department of Pharmacognosy, Faculty of Pharmacy, Kabul University.

\subsection{Induction of Morphine Dependency and Withdrawal Signs}

For induction of morphine dependency, rats received a subcutaneous injection of morphine hydrochloride for 4 
days in 7 times. The doses of morphine were 10, 20, and $40 \mathrm{mg} / \mathrm{kg}$ twice daily on the first to a third day, respectively, which followed by a single dose of $60 \mathrm{mg} / \mathrm{kg}$ on the fourth day. To induce withdrawal signs, $3 \mathrm{mg} / \mathrm{kg}$ dose of Naloxone was administrated intraperitoneally (i.p.) after two hours of $7^{\text {th }}$ morphine injection. [37]. Thereafter, five distinct withdrawal signs (jumping, teeth chattering, rearing, paw tremor, and defecation) were monitored in a glass cylinder during a 30-min period. After the placing of each rat in the cylinder, the intra-cylinder sawdust was changed to remove all smell cues.

\subsection{Experimental Groups}

Rats were randomly divided into 13 groups $(\mathrm{n}=6)$ :

1. Normal group: Normal rats received Normal saline (1 ml, i.p.) for 4 days;

2. Morphine group: Morphine-dependent rats received Normal saline ( $1 \mathrm{ml}$, i.p.) for 4 days;

3-6. FAAE 25, 50, 75, $100 \mathrm{mg} / \mathrm{kg}$ groups: Morphine-dependent rats received FAAE $(25,50,75$ and $100 \mathrm{mg} / \mathrm{kg}$, respectively, i.p.) for 4 days simultaneously with morphine.

7-10. CSAE 25, 50, 100, $150 \mathrm{mg} / \mathrm{kg}$ groups: Morphine-dependent rats received CSAE (25, 50, 100 and $150 \mathrm{mg} / \mathrm{kg}$, respectively, i.p.) for 4 days simultaneously with morphine.

11-13. FAAE+CSAE Combination groups: Morphine-dependent rats received combinations of FAAE+CSAE $(100 \mathrm{mg} / \mathrm{kg}+150 \mathrm{mg} / \mathrm{kg}, \quad 25 \mathrm{mg} / \mathrm{kg}+50$ $\mathrm{mg} / \mathrm{kg}, 50 \mathrm{mg} / \mathrm{kg}+25 \mathrm{mg} / \mathrm{kg}$, respectively, i.p.) for 4 days simultaneously with morphine.

Since the combination of FAAE $100 \mathrm{mg} / \mathrm{kg}+$ CSAE $150 \mathrm{mg} / \mathrm{kg}$ and FAAE $25 \mathrm{mg} / \mathrm{kg}+$ CSAE $50 \mathrm{mg} / \mathrm{kg}$ were toxic and killed all rats of the groups within few hours, these groups were excluded from the experiment.

\subsection{Statistical Analysis}

Using Graph pad prism (6.07), each morphine withdrawal signs recorded in rats was statistically analyzed by unpaired, two-tailed t-test or non-parametric Kruskal-Wallis and Mann-Whitney U tests. Multiple comparisons were done by One-Way ANOVA test $(\mathrm{P}<0.05)$. The results are showed as mean \pm SEM.

\section{Results}

\subsection{Effect of FAAE on Withdrawal Signs}

In this study, following the i.p. injection of naloxone hydrochloride, morphine-treated rats showed morphine withdrawal signs. There was a considerable increase in the number of jumping $(2.5 \pm 0.62)$, teeth chattering (5.50 \pm 0.88$)$, rearing $(29.83 \pm 6.18)$, paw tremor $(9.33 \pm 1.58)$, and defecation $(4.00 \pm 0.86)$ in the morphine group than the normal group $(\mathrm{P}<0.01)$ (Fig. 1). Also, the number of jumping was considerably decreased in FAAE $25 \mathrm{mg} / \mathrm{kg}(0.33 \pm 0.21)(\mathrm{P}<0.01)$, but not in FAAE 50 $(0.67 \pm 0.21), 75(1.00 \pm 0.26)$ and $100 \mathrm{mg} / \mathrm{kg}(0.67 \pm 0.21)$ groups, as compared with morphine group $(2.50 \pm 0.62)$ (P>0.05, Fig. 2A). A considerable difference was seen in the number of rearing only between FAAE $100 \mathrm{mg} / \mathrm{kg}$ $(15.17 \pm 1.58)$ and morphine groups $(29.83 \pm 6.18)$, but not in FAAE $25(22.67 \pm 2.54), 50(23.67 \pm 3.55)$, and $75 \mathrm{mg} / \mathrm{kg}$ groups (19.17 \pm 4.49$)(\mathrm{P}>0.05$, Fig. 2B). The number of teeth chattering was significantly decreased in each FAAE $25(1.33 \pm 0.80), 50(0.50 \pm 0.50), 75(0.67 \pm 0.33)$ and 100 $\mathrm{mg} / \mathrm{kg}(0.83 \pm 0.54)$ groups, in comparison with the morphine group $(5.50 \pm 0.88)(\mathrm{P}<0.05$, Fig. $2 \mathrm{C})$. Also, a considerable decrease was seen in the number of paw tremor in each FAAE $25(0.83 \pm 0.17), 50(0.50 \pm 0.34), 75$ $(0.83 \pm 0.17)$ and $100 \mathrm{mg} / \mathrm{kg}(0.67 \pm 0.33)$ groups and morphine group $(9.33 \pm 1.58)(\mathrm{P}<0.01$, Fig. $2 \mathrm{D})$. Further, the incidence of defecation was considerably decreased only in FAAE $100 \mathrm{mg} / \mathrm{kg}(1.00 \pm 0.36)(\mathrm{P}<0.05)$, but not in FAAE $25(3.33 \pm 0.76), 50(3.83 \pm 0.79)$ and $75 \mathrm{mg} / \mathrm{kg}$ $(1.67 \pm 0.42)$ groups, as compared with morphine group $(4.00 \pm 0.86)(\mathrm{P}>0.05$, Fig. 2E). 

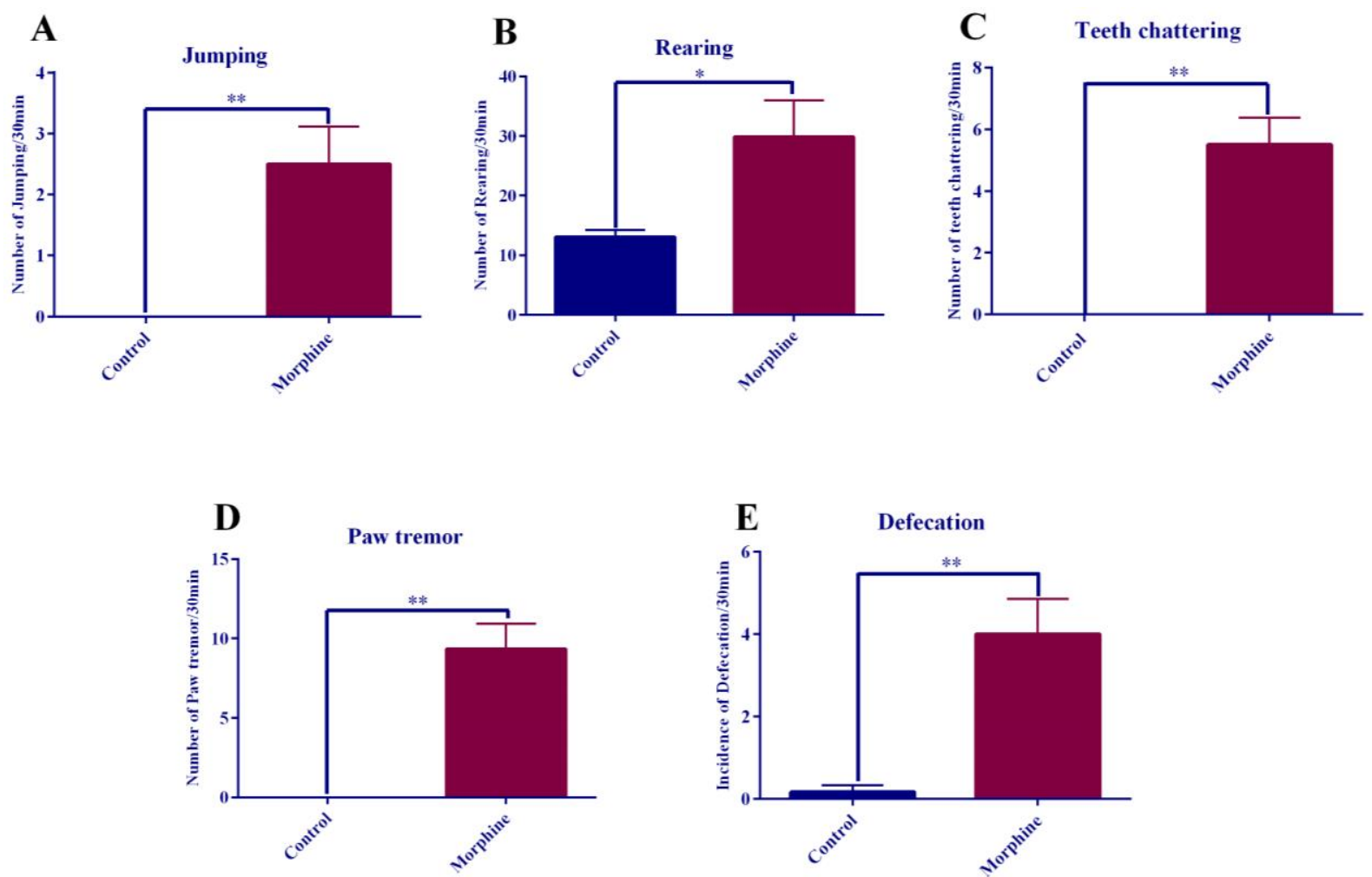

Figure 1. Naloxone-induced morphine withdrawal signs. The number of various withdrawal signs, including jumping, rearing, teeth chattering, paw tremor, chewing, and penis licking (A-E) was considerably increased in the morphine group in comparison with control group. Data were expressed as mean \pm SEM. ${ }^{*}: \mathrm{P}<0.05,{ }^{* *}: \mathrm{P}<0.01$.
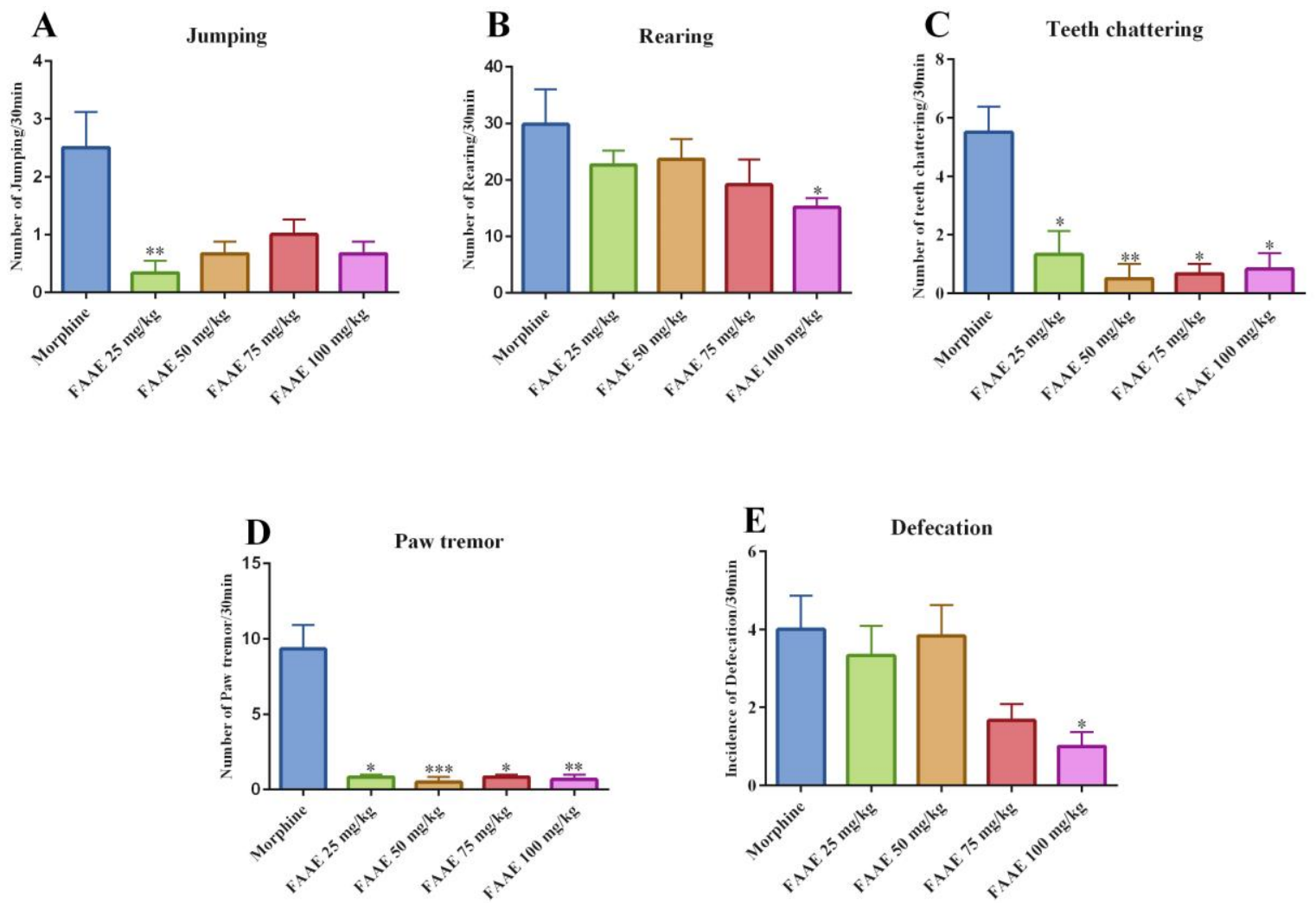

Figure 2. Effect of $\operatorname{FAAE}(25,50,75$, and $100 \mathrm{mg} / \mathrm{kg})$ on the morphine withdrawal signs. The number of various withdrawal signs, including jumping, rearing, teeth chattering, paw tremor, and defecation (A-E) was considerably decreased in FAAE groups, as compared with the morphine group. Data were expressed as mean \pm SEM. ${ }^{*}: \mathrm{P}<0.05,{ }^{* *}: \mathrm{P}<0.01,{ }^{* * *}: \mathrm{P}<0.001$. FAAE: Ferula assa-foetida aqueous extract. 

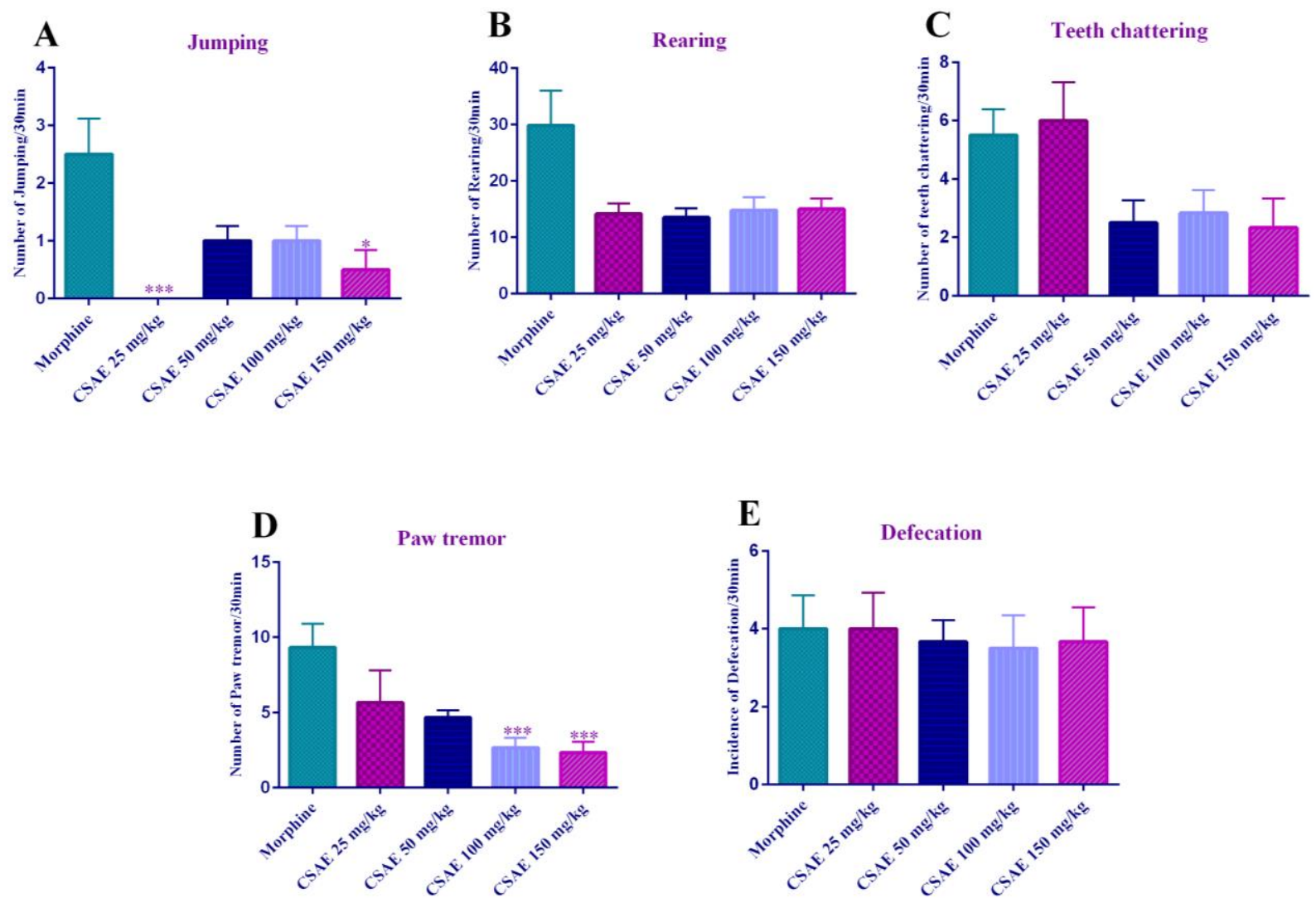

Figure 3. Effect of $\operatorname{CSAE}(25,50,100$ and $150 \mathrm{mg} / \mathrm{kg})$ on the morphine withdrawal signs. The number of various withdrawal signs, including jumping and paw tremor (A, D) was significantly decreased in CSAE groups than the morphine group. There was not a considerable difference in the number of rearing, teeth chattering, and defecation $(B, C, E)$ between CSAE groups and the morphine group. Data were expressed as mean \pm SEM. ${ }^{*}$ : $\mathrm{P}<0.05,{ }^{* * *}: \mathrm{P}<0.001$. CSAE: Crocus sativus aqueous extract.

\subsection{Effect of CSAE on Withdrawal Signs}

The number of jumping was considerably decreased in CSAE $25 \quad(0.00 \pm 0.00)$ and $150 \mathrm{mg} / \mathrm{kg} \quad(0.50 \pm 0.34)$ $(\mathrm{P}<0.05)$, but not in CSAE $50(1.00 \pm 0.26)$ and $100 \mathrm{mg} / \mathrm{kg}$ $(1.00 \pm 0.26)$ groups, as compared with morphine group $(2.50 \pm 0.62) \quad(\mathrm{P}>0.05$, Fig. 3A). There was not a considerable difference in the number of rearing between neither of CSAE $25(14.17 \pm 1.81), 50(13.50 \pm 1.67), 100$ $(14.83 \pm 2.29)$ and $150 \mathrm{mg} / \mathrm{kg}(15.00 \pm 1.88)$ groups and the morphine group (29.83 \pm 6.18$)(\mathrm{P}>0.05$, Fig. 3B). Also, the number of teeth chattering was not decreased in either of CSAE $25(6.00 \pm 1.32), 50(2.50 \pm 0.76), 100(2.83 \pm 0.79)$ and $150 \mathrm{mg} / \mathrm{kg}(2.33 \pm 0.99)$ groups, as compared with the morphine group (5.50 \pm 0.88$)$ ( $\mathrm{P}>0.05$, Fig. 3C). However, a considerable decrease was seen in the number of paw tremor in CSAE $100(2.67 \pm 0.67)$ and $150 \mathrm{mg} / \mathrm{kg}$ $(2.33 \pm 0.71)$ groups $(\mathrm{P}<0.001)$, but not in $25(5.67 \pm 2.14)$ and $50 \mathrm{mg} / \mathrm{kg}(4.67 \pm 0.49)$ groups, in comparison with morphine group $(9.33 \pm 1.58)(\mathrm{P}>0.05$, Fig. 3D). Further, the incidence of defecation was not considerably decreased in CSAE 25 (4.00 \pm 0.93$), 50$ (3.67 \pm 0.56$), 100$ $(3.50 \pm 0.85)$ and $150 \mathrm{mg} / \mathrm{kg}(3.67 \pm 0.88)$ groups, as compared with the morphine group $(4.00 \pm 0.86)(\mathrm{P}>0.05$, Fig. 3E).

\subsection{Effect of FAAE and CSAE Combination on Withdrawal Signs}

A considerable reduction was seen in the number of jumping $(0.33 \pm 0.33)$ and teeth chattering $(1.17 \pm 0.54)$ in the combination group in comparison with the morphine group $(\mathrm{P}<0.05)$. However, there was not a considerable difference in number of rearing $(14.67 \pm 4.04)$, paw tremor $(8.33 \pm 3.97)$ and incidence of defecation $(3.33 \pm 0.84)$ in the combination group, in comparison with the morphine group ( $\mathrm{P}>0.05$, Fig. 4). 

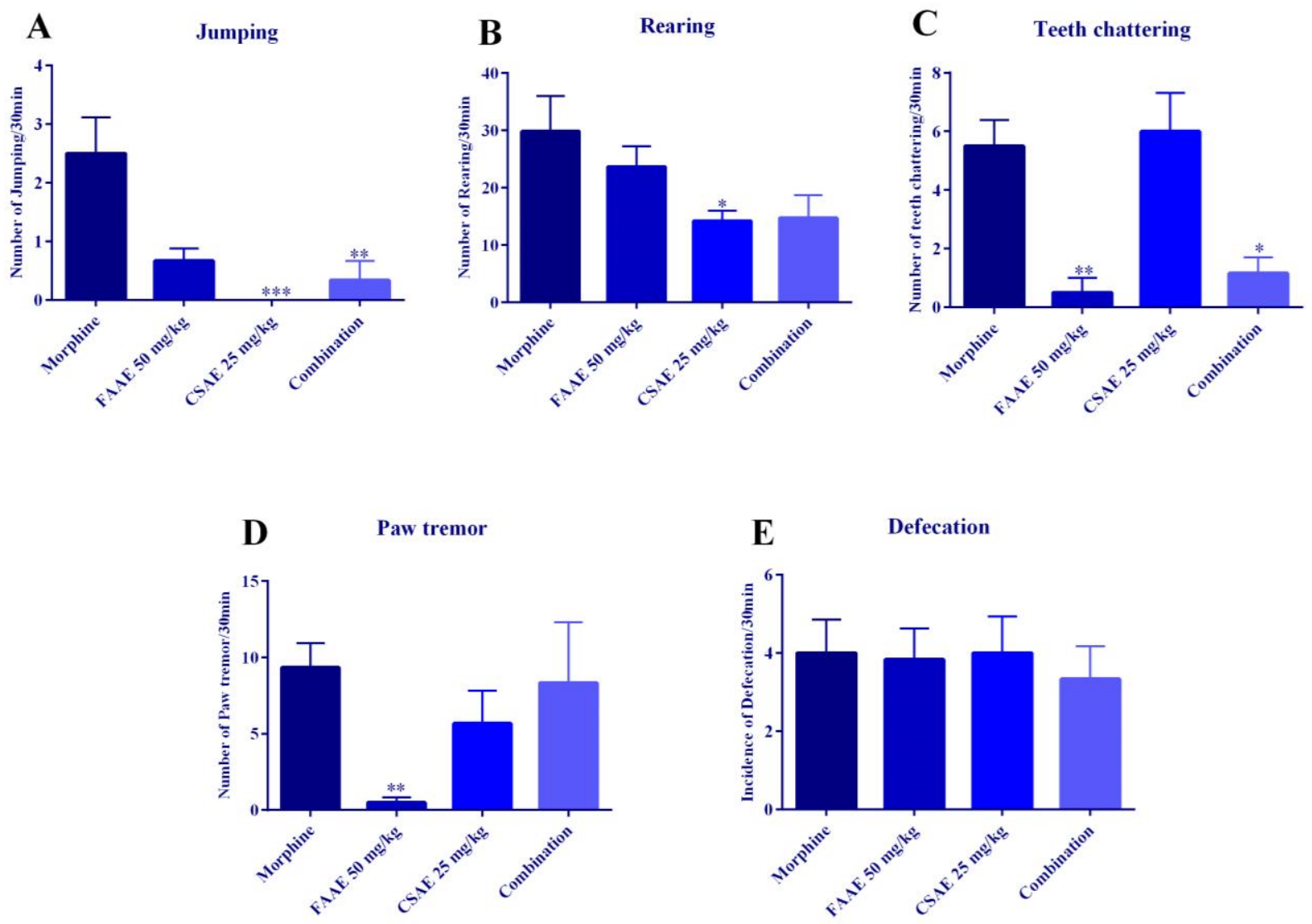

Figure 4. Effect of FAAE $50 \mathrm{mg} / \mathrm{kg}$, CSAE $25 \mathrm{mg} / \mathrm{kg}$ and their combination on the morphine withdrawal signs. The number of various withdrawal signs, including jumping and teeth chattering $(\mathrm{A}, \mathrm{C})$ was considerably decreased in the combination group, as compared with the morphine group. There was not a considerable difference in the number of rearing, paw tremor, and defecation (B, C, E) between combination and morphine groups. Data were expressed as mean \pm SEM. ${ }^{*}: \mathrm{P}<0.05,{ }^{* *}: \mathrm{P}<0.01,{ }^{* * *}: \mathrm{P}<0.001$. FAAE: Ferula assa-foetida aqueous extract; CSAE: Crocus sativus aqueous extract.

\section{Discussion}

The effect of FAAE and CSAE either alone or in combination was evaluated on the number of jumping, rearing, teeth chattering, paws tremor and defecation. Based on results, the number of these signs was considerably increased following administration of naloxone in morphine-dependent rats. Therefore, one can conclude that administration of morphine hydrochloride for 4 days rendered morphine-dependency in rats. In addition, simultaneous administration of FAAE with morphine could decrease the number of morphine withdrawal signs in rats. $25 \mathrm{mg} / \mathrm{kg}$ of FAAE could decrease the number of paw tremor, jumping, and teeth chattering in rats. A considerable reduction in the number of paw tremor and teeth chattering was seen in FAAE 50 and $75 \mathrm{mg} / \mathrm{kg}$-treated groups. However, $100 \mathrm{mg} / \mathrm{kg}$ dose of FAAE could decrease most of the withdrawal signs including rearing, teeth chattering, paw tremor and defecation, as compared with morphine group. As a result, $100 \mathrm{mg} / \mathrm{kg}$ dose of FAAE is considered as its most-effective dose on the number of morphine withdrawal signs.
Similarly, past studies showed that Ferula assa-foetida different parts including aerial parts, flower and root could decrease the number of morphine withdrawal signs. It suggested that this positive effect is highly related to their active constituents such as ferulic acid, caffeic acid and alpha- and beta-pinene [29].

There are many reports that Locus coeruleus is considered as the most-sensitive area for development of withdrawal signs in morphine-dependent rats. Excitation of its neuronal activity leads to a significant increase in withdrawal signs [9]. On the other hand, there are pieces of evidence that free radicals including nitric oxide are considered endogenous modulators of long-term opioid effects. Locus coeruleus activity due to the presence of nitric oxide signalling proteins can be modulated by the nitric oxide pathway, so the administration of nitric oxide synthase inhibitors can decrease the morphine withdrawal signs $[4,33,34]$.

On the other hand, studies showed that ferulic acid could inhibit nitric oxide isoforms including iNOS and nNOS [31]. In addition, isolated caffeic acid from Ferula assa-foetida also can inhibit LPS-induced nitric oxide production [32]. As the Ferula assa-foetida oleo gum 
resin is greatly constituted by resin compounds such as caffeic acid and ferulic acid [25,26], the positive effects of FAAE on morphine withdrawal signs probably resulted from the presence of these constituents. Therefore, one can conclude that administration of FAAE can inhibit nitric oxide synthase and decrease the nitric oxide isoforms production. This can lead to a decrease in neuronal activity of Locus coeruleus and therefore decrease in morphine withdrawal signs.

Furthermore, based on the present study, administration of CSAE also can decrease the number of morphine withdrawal signs. Only the number of jumping could alleviate by $25 \mathrm{mg} / \mathrm{kg}$ dose of CSAE. CSAE in dose of 50 $\mathrm{mg} / \mathrm{kg}$ didn't show any significant effect on neither of the withdrawal signs. Similarly, $100 \mathrm{mg} / \mathrm{kg}$ of CSAE only could decrease the paw tremor in rats. However, administration of $150 \mathrm{mg} / \mathrm{kg}$ CSAE was effective on the number of jumping and paw tremor in morphine-dependent rats. Therefore, $150 \mathrm{mg} / \mathrm{kg}$ dose of CSAE was considered as its most effective dose on morphine withdrawal signs.

Similarly, previous studies also showed the beneficial effect of CSAE on morphine withdrawal signs. A previous study showed that CSAE in 40, 160 and $320 \mathrm{mg} / \mathrm{kg}$ could decrease the withdrawal signs significantly [40]. Another study has shown that administration of CSAE in 100 and $150 \mathrm{mg} / \mathrm{kg}$ doses for 7 days could decrease the morphine withdrawal signs. This study was also considered 150 $\mathrm{mg} / \mathrm{kg}$ dose of CSAE as its most effective dose on withdrawal signs [37]. Both studies confirm the results of the present study.

Based on previous studies, it's probable that positive effects of CSAE on withdrawal signs are related to its active constituents including crocin, because the administration of crocin in morphine-dependent rats can lead to a reduction in the number of withdrawal signs [40]. Also, previous studies suggest that CSAE due to its effects on the facilitation of GABA actions through GABA-A benzodiazepine receptor may increase the frequency of chloride channels and induce hyperpolarization. This can lead to anti-anxiety and sedative effects and thereby reduce the morphine withdrawal signs [37]. As CSAE can increase the dopamine level in the brain of rats [41], probably, dopamine decreases the release of norepinephrine through its interaction with D2 receptors in nucleus accumbence and thus decrease in norepinephrine release can alleviate morphine withdrawal signs [37].

Moreover, this study evaluates the effect of FAAE and CSAE combinations on morphine withdrawal signs. First, the most effective doses of FAAE $(100 \mathrm{mg} / \mathrm{kg})$ and CSAE $(150 \mathrm{mg} / \mathrm{kg})$ were combined. However, combined administration of these doses showed acute toxicity in rats, so killed all rats of the group within few hours. Then, the $25 \mathrm{mg} / \mathrm{kg}$ of FAAE and $50 \mathrm{mg} / \mathrm{kg}$ of CSAE were combined, but administration of this combination has also killed all rats of the group within the first day. Thereafter, the $50 \mathrm{mg} / \mathrm{kg}$ of FAAE and $25 \mathrm{mg} / \mathrm{kg}$ of CSAE were combined; this combination didn't show any toxic effects and alleviates the withdrawal signs including teeth chattering and jumping in morphine-dependent rats. Therefore, one can conclude that the combination of FAAE and CSAE in high doses is very toxic in morphine-dependent rats, but their combination in low doses can alleviate the morphine withdrawal signs. However, the effect of their combination is not great as each individual herb. Therefore, it seems that FAAE and CSAE don't have any synergic effect on morphine-dependent rats.

\section{Conclusions}

All in all, one can conclude that administration of different doses of FAAE and CSAE and their combination (in low doses) can decrease the morphine withdrawal signs. However, their combination in high doses is very toxic. A combination of low doses of FAAE and CSAE didn't show any synergic effect on morphine withdrawal signs.

\section{Acknowledgements}

This study is supported by Khatam Al-Nabieen university research and technology center (KNURTC), Kabul, Afghanistan. We thank all officials for their valuable support in providing the experiment and facilities for this study.

\section{REFERENCES}

[1] Seyedi SY., Salehi F., Payandemehr B., Hossein S., Hosseini - Zare MS., Nassireslami E., Yazdi BB., Sharifzadeh M., "Dual effect of cAMP agonist on ameliorative function of PKA inhibitor in morphine dependent mice", Fundamental \& clinical pharmacology, vol. 28, no. 4, pp. 445-454., 2014. https://doi.org/10.1111/fcp.12045

[2] Kim J., Ham S., Hong H., Moon C., Im HI., "Brain reward circuits in morphine addiction", Molecules and cells, vol. 39, no. 9, pp. 645-653, 2016. https://doi.org/10.14348/molcells.2016.0137

[3] Chaves C., Remiao F., Cisternino S., Decleves X., "Opioids and the blood-brain barrier: a dynamic interaction with consequences on drug disposition in brain", Current neuropharmacology, vol. 15, no. 8, pp. 1156-1176, 2017. https://doi.org/10.2174/1570159X15666170504095823

[4] Santamarta MT., Ulibarri I., Pineda J., "Inhibition of neuronal nitric oxide synthase attenuates the development of morphine tolerance in rats", Synapse, vol. 57, no. 1, pp. 38-46, 2005. https://doi.org/10.1002/syn.20151 
[5] Bie B., Peng Y., Zhang Y., Pan ZZ., "cAMP-mediated mechanisms for pain sensitization during opioid withdrawal", Journal of Neuroscience, vol. 25, no. 15, pp. 3824-3832, https://doi.org/10.1523/JNEUROSCI.5010-04.2005

[6] Koob GF., Ahmed SH., Boutrel B., Chen SA., Kenny PJ., Markou A., O'Dell LE., Parsons LH., Sanna PP., "Neurobiological mechanisms in the transition from drug use to drug dependence", Neuroscience \& Biobehavioral Reviews, vol. 27, no. 8, pp. 739-749, 2004. https://doi.org/10.1016/j.neubiorev.2003.11.007

[7] De Vries TJ., Shippenberg TS., "Neural systems underlying opiate addiction", Journal of Neuroscience, vol. 22, no. 9, pp, 3321-3325, 2002.https://doi.org/10.1523/JNEUROSCI .22-09-03321.2002

[8] Ebrahimie M., Bahmani M., Shirzad H., Rafieian-Kopaei M., Saki K., "A review study on the effect of Iranian herbal medicines on opioid withdrawal syndrome", Journal of evidence-based complementary \& alternative medicine, vol. 20, no. 4, pp. 302-309, 2015 https://doi.org/10.1177\%2F2156587215577896

[9] Mousavi Y., Azizi H., Mirnajafi-Zadeh J., Javan M., Semnanian S., "Blockade of orexin type-1 receptors in locus coeruleus nucleus attenuates the development of morphine dependency in rats", Neuroscience letter, vol. 578, pp. 90-94, 2014. https://doi.org/10.1016/j.neulet.2014.06.0 38

[10] Fakhari M., Azizi H., Semnanian S., "Central antagonism of orexin type-1 receptors attenuates the development of morphine dependence in rat locus coeruleus neurons", Neuroscience, vol. 363, pp. 1-10, 2017. https://doi.org/10.1016/j.neuroscience.2017.08.054

[11] Abdollahi H., Ghaemi-Jandabi M., Azizi H., Semnanian S., "The role of orexin type-1 receptors in the development of morphine tolerance in locus coeruleus neurons: An electrophysiological perspective", Brain Research, vol. 1646, pp. 91-97, 2016.https://doi.org/10.1016/j.brainres.20 16.05.043

[12] Ghaemi-Jandabi M., Azizi H., Ahmadi-Soleimani SM., Semnanian S., "Intracoerulear microinjection of orexin-A induces morphine withdrawal-like signs in rats", Brain Research Bulletin, vol. 130, pp. 107-111, 2017. https://doi.org/10.1016/j.brainresbull.2017.01.010

[13] Kaeidi A., Azizi H., Javan M., Soleimani SM., Fathollahi Y., Semnanian S., "Direct facilitatory role of paragigantocellularis neurons in opiate withdrawal-induced hyperactivity of rat locus coeruleus neurons: an in vitro study", PloS One, vol. 10, no. 7, pp. e0134873, 2015. https://doi.org/10.1371/journal.pone.0134873

[14] Ahmadi-Soleimani SM., Ghaemi-Jandabi M., Azizi H., Semnanian S., "Orexin type 1 receptor antagonism in Lateral Paragigantocellularis nucleus attenuates naloxone precipitated morphine withdrawal symptoms in rats", Neuroscience Letter, vol. 558, pp. 62-66, 2014. https://doi.org/10.1016/j.neulet.2013.10.064

[15] Ahmadi-Soleimani SM., Azizi H., Gompf HS., Semnanian S., "Role of orexin type-1 receptors in paragiganto-coerulear modulation of opioid withdrawal and tolerance: a site specific focus", Neuropharmacology, vol. 126, pp. 25-37, 2017. https://doi.org/10.1016/j.neuropharm

\section{.2017 .08 .024}

[16] Alami K., Mousavi SY., "Afghan Chehelghoza (Pinus gerardiana L.) Pine Nut Diet Enhances the Learning and Memory in Male Rats", Nutrition and Dietary Supplements, vol. 12, pp. 277-288, 2020. https://doi.org/10.2147/NDS.S 278350

[17] Alami K., Mousavi SY., "Effect of Afghan chehelghoza (Pinus gerardiana L.) on Food Consumption, Body, and Brain Weight of Male Rats", Journal of Complementary Medicine Research, vol. 12, no. 1, pp. 5-8, 2021. https://doi.org/10.5455/jcmr.2021.12.01.02

[18] Alami K., Haidari M., Ebrahimi K., Bakhtiari AA., Sajjadi M., Mousavi SY., "Effect of Afghan Senjed (Elaeagnus Angustifolia L.) Leaves Aqueous Extract on Memory of Male Rats", International Journal of Ayurvedic Medicine, vol. 12, no. 1, pp. 62-67, 2021. https://doi.org/10.47552/ijam.v12i1.1765

[19] Sadat H., Alami K., Mousavi SY., "Effect of Afghan Senjed (Elaeagnus angustifolia L.) leaves aqueous alcoholic extract on blood glucose level of diabetic rats", Pharmacognosy Journal, vol. 12, no. 6, pp. 1218-1222, 2020 https://doi.org/10.5530/pj.2020.12.170

[20] Hussaini ZS., Askndari H., Alami K., Mousavi SY., "Effect of Rheum Ribes and Urtica Dioica on type 2 diabetic rats", International Journal of Pharmaceutical and Phytopharmacological Research (eIJPPR), vol. 11, no. 1, pp. 63-69, 2021.

[21] Haidari M., Alami K., Hossaini A., Mousavi SY., "Effect of Afghan Hibiscus sabdariffa L. and Carum Carvi L. Hydro-alcoholic Extracts Either Alone or in Combination on Blood Glucose Level in Diabetic Rats", International Journal of Ayurvedic Medicine, vol. 11, no. 4, pp. 759-764, 2020. https://doi.org/10.47552/ijam.v11i4.1691

[22] Patrick EE., Item A., Eyong UE., Godwin EE., "The Antidiabetic efficacy of combined extracts from two continental plants: Azadirachta indica (A. Juss)(Neem) and Vernonia amygdalina (Del.)(African Bitter Leaf)", Amrican Journal of Biochemistry and Biotechnology, vol. 4, pp. 239-244, 2008.

[23] Zare AR., Solouki M., Omidi M., Iravani N., Oladzad Abasabadi A., Mahdi Nezad N., "Effect of various treatments on seed germination and dormancy breaking in Ferula assa foetida L.(Asafetida), a threatened medicinal herb", Trakia Journal of Sciences, vol. 9, no. 2, pp. 57-61, 2011. http://dx.doi.org/10.29252/yujs.3.2.155

[24] Iranshahy M., Iranshahi M., "Traditional uses, phytochemistry and pharmacology of asafoetida (Ferula assa-foetida oleo-gum-resin)-A review", Journal of Ethnopharmacology, vol. 134, no. 1, pp. 1-10, 2011. https://doi.org/10.1016/j.jep.2010.11.067

[25] Bagheri SM., Dashti-R MH., Morshedi A., "Antinociceptive effect of Ferula assa-foetida oleo-gum-resin in mice", Research in Pharmaceutical Science, vol. 9, no. 3, pp. 207-212, 2014.

[26] Iranshahi M., Alizadeh M., "Antihyperglycemic effect of Asafoetida (Ferula assafoetida Oleo-Gum-Resin) in streptozotocin-induced diabetic rats", World Applied Sciences Journal, vol. 17, no. 2, pp. 157-162, 2012. 
[27] Dehpour AA., Ebrahimzadeh MA., Fazel NS., Mohammad NS., "Antioxidant activity of the methanol extract of Ferula assafoetida and its essential oil composition" Grasas y aceites, vol. 60, no. 4, pp. 405-412, 2009. https://doi.org/10.3989/gya.010109

[28] Bagheri SM., Hedesh ST., Mirjalili A., Dashti-r MH., "Evaluation of anti-inflammatory and some possible mechanisms of antinociceptive effect of Ferula assa foetida oleo gum resin", Evidence-Based Complementary and Alternative Medicine, vol. 21, no. 4, pp. 271-276, 2016. https://doi.org/10.1177/2156587215605903

[29] Khanavi M., Maadani S., Farahanikia B., Eftekhari M., Sharifzadeh M., "Effect of the methanolic extracts of different parts of Ferula assa-foetida on naloxone-induced withdrawal behavior in morphine-dependent mice", Avicenna Journal of Phytomedicine, vol. 7, no. 5, pp. 426435, 2017.

[30] Hossaini D., Alami K., Nazari ML., Ebrahimi K., Salehi MH., Mousavi SY., "Effect of Afghan Ferula assa-foetida L. oleo Gum Resin Aqueous Extract on Withdrawal Signs in Morphine-Dependent Rats", Journal of Complementary Medicine Research, vol. 12, no. 1, pp. 70-74, 2021. https://doi.org/10.5455/jcmr.2021.12.01.07

[31] Koh PO., "Ferulic acid modulates nitric oxide synthase expression in focal cerebral ischemia", Laboratory Animal Research, vol. 28, no. 4, pp. 273-278, 2012. https://doi.org/10.5625/lar.2012.28.4.273

[32] de Guglielmo G., Kallupi M., Scuppa G., Stopponi S., Demopulos G., Gaitanaris G., Ciccocioppo R., "Analgesic tolerance to morphine is regulated by PPAR $\gamma$ ", British journal of pharmacology, vol. 171, no. 23, pp. 5407-5416, 2014. https://doi.org/10.1111/bph.12851

[33] Mori T., Ito S., Matsubayashi K., Sawaguchi T., "Comparison of nitric oxide synthase inhibitors, phospholipase A2 inhibitor and free radical scavengers as attenuators of opioid withdrawal syndrome", Behavioral Pharmacology, vol. 18, no. 8, pp. 725-729, 2007. http://doi.org/10.1097/FBP.0b013e3282f18da6

[34] Uzbay IT., Oglesby MW., "Nitric oxide and substance dependence", Neuroscience \& Biobehavioral Reviews, vol. 25, no. $1, \quad$ pp. 43-52, 2001.
https://doi.org/10.1016/S0149-7634(00)00049-X

[35] Rahaiee S., Moini S., Hashemi M., Shojaosadati SA., "Evaluation of antioxidant activities of bioactive compounds and various extracts obtained from saffron (Crocus sativus L.): a review", Journal of food science and technology, vol. 52, no. 4, pp. 1881-1888, 2015. https://doi.org/10.1007/s13197-013-1238-x

[36] Baba SA., Malik AH., Wani ZA., Mohiuddin T., Shah Z., Abbas N., Ashraf N., "Phytochemical analysis and antioxidant activity of different tissue types of Crocus sativus and oxidative stress alleviating potential of saffron extract in plants, bacteria, and yeast", South African Journal of Botany, vol. 99, pp. 80-87, 2015. https://doi.org/10.1016/j.sajb.2015.03.194

[37] Akbari E., Alami K., Hossaini D., Nazari ML., Salehi MH., Sajjadi M., Mousavi SY., "Effect of Afghan Saffron (Crocus sativus L.) aqueous extract on withdrawal signs in morphine-dependent rats", Pharmacognosy Journal, vol. 12, no. 6s, pp. 1727-1731, 2020. https://doi.org/10.5530/pj.2020.12.234

[38] Naghibi SM., Hosseini M., Khani F., Rahimi M., Vafaee F., Rakhshandeh H., Aghaie A., "Effect of aqueous extract of Crocus sativus L. on morphine-induced memory impairment", Advances in pharmacological sciences, vol. 2012, pp. 7, 2012. https://doi.org/10.1155/2012/494367

[39] Hosseinzadeh H., Younesi HM., “Antinociceptive and anti-inflammatory effects of Crocus sativus L. stigma and petal extracts in mice", BMC pharmacology, vol. 2, no. 1, pp. 7, 2002. https://doi.org/10.1186/1471-2210-2-7

[40] Hosseinzadeh H., Jahanian Z., "Effect of Crocus sativus L. (saffron) stigma and its constituents, crocin, and safranal, on morphine withdrawal syndrome in mice", Phytotherapy Research: An International Journal Devoted to Pharmacological and Toxicological Evaluation of Natural Product Derivatives, vol. 24, no. 5, pp. 726-730, 2010. https://doi.org/10.1002/ptr.3011

[41] Ettehadi H., Mojabi SN., Ranjbaran M., Shams J., Sahraei H., Hedayati M., Asefi F., "Aqueous extract of saffron (Crocus sativus) increases brain dopamine and glutamate concentrations in rats", Journal of behavioral brain research, vol. 3, $\quad$ pp. $315-319, \quad 2013$. http://doi.org/10.4236/jbbs.2013.33031 